\title{
MEMBACA GELIAT PENDIDIKAN DAN KEILMUAN DI SPANYOL ISLAM (TAHUN: 756-1494 M.)
}

\section{Hadi Masruri}

Fakultas Ilmu Tarbiyah dan Keguruan Universitas Islam Negeri Maulana Malik Ibrahim Malang e-mail: hadimasruri@ymail.com

\begin{abstract}
This paper is about to assert that the triumph of science in the Islamic Spain didn't only occur in the period following the Umayyad dynasty II (c. 756-1031), but quite the dynasty during the reign of al-Muwahhidun (1078-1214) and reached its peak under the the reign of the Caliph Abu Yusuf Ya'qub al-Mansur (d. 580 h./1184 M). The intellectual glory of Andalusia marked several things: first, expedition scientists massively in the Umayyad II to the Eastern Islamic world in order to study and acquire as many references to the development of science upon his return to their Islamic Spain; Second, the migration of scientists to Eastern Andalusia happened in al-Muwahhidun dynasty is the transmission of knowledge from the East to the Islamic Spain; and the third, the translation movement in the $12^{\text {th }}$ century and $13^{\text {rd }}$ based in Toledo can be seen is the bridge to the current scientific knowledge of the Arab world to Europe, Islam is encouraged intellectual progress stretching in Andalusia.
\end{abstract}

Keywords: Intellectual, Academic, Transmission of the expedition scientists.

Abstrak: Tulisan ini hendak menegaskan bahwa kejayaan keilmuan di masa Spanyol Islam tidak terjadi pada masa kekuasan dinasti Umayyah II (tahun 756-1031) saja, melainkan justru pada masa pemerintahan dinasti al-Muwahhidun (1078-1214) dan mencapai puncaknya di bawah pemerintahan khalifah Abu Ya'qub Yusuf al-Manshur (w. 580 H./1184 M). Kejayaan intelektual di Andalusia ditandai beberapa hal: pertama, ekspedisi para ilmuwan secara besar-besaran di masa Umayyah II ke dunia Islam Timur guna menuntut ilmu dan memperoleh referensi sebanyakbanyaknya untuk pengembangan ilmu pengetahuan sekembalinya mereka ke Spanyol Islam; kedua, migrasi para ilmuwan Timur ke Andalusia yang terjadi di masa dinasti al-Muwahhidun merupakan transmisi ilmu pengetahuan dari wilayah Timur ke Spayol Islam; dan yang ketiga, gerakan penerjemahan di abad ke-12 dan 13 yang berpusat di Toledo dapat dipandang merupakan jembatan bagi arus keilmuan Arab Islam ke dunia Eropa, adalah hal yang mendorong geliat kemajuan intelektual di Andalusia.

Kata-kata Kunci: Kemajuan Intelektual, Transmisi Keilmuan, Ekspedisi Ilmuwan. 


\section{Pendahuluan}

Pembacaan ulang (i'adat al-qira'ah) terhadap khazanah masa lalu (turats) hingga kini masih jarang dilakukan, terutama dalam konteks menemukan sebuah model pendidikan atau bahkan dilupakan oleh para pakar pendidikan modern sekalipun. Hal ini, di antaranya disebabkan oleh adanya kecenderungan manusia modern, terutama di Indonesia yang sering mengabaikan masa lalu dan memandang masa lalu hanya sebatas bagian dari kehidupan manusia, tanpa memetik ibrah dari peristiwa yang terjadi di masa lalu. Upaya pembacaan terhadap masa lalu merupakan salah satu bentuk memunculkan kembali kesadaran historis (alwa'y al-tarikhi) untuk tujuan menemukan identitas diri suatu bangsa guna menyongsong kemajuan dan kejayaan di masa yang akan dating (Sartono Kartodirdjo, 1993, 6-8).

Periode Spanyol Islam yang dikenal sebagai Andalusia pernah berjaya dalam rentang waktu yang cukup panjang, sejak masuknya Islam pertama kali di masa dinasti Umayyah tahun $711 \mathrm{M}$. di tangan panglima perangnya Thariq ibn Ziyad (w. tahun 720 M.) sampai kekuasaan bani Ahmar (1248-1492 M.). Spanyol Islam pada periode klasik dalam sejarahnya yang panjang (610-1250 M), dipandang oleh para sejarawan sebagai masa pengembangan peradaban Islam awal hingga mencapai puncak kejayaan, yaitu: 1) Periode pembinaan pendidikan Islam, yang berlangsung pada zaman nabi Muhammad saw; 2) Periode pertumbuhan pendidikan Islam, yang berlangsung sejak Muhammad saw wafat sampai akhir Bani Umayyah, yang ditandai dengan berkembangnya ilmu-ilmu naqliah; 3) Periode kejayaan (puncak perkembangan) pendidikan Islam, yang berlangsung sejak permulaan daulah Abbasiyah sampai dengan jatuhnya Baghdad, yang diwarnai oleh berkembangnya ilmu akliah dan timbulnya madrasah, serta memuncaknya perkembangan kebudayaan Islam; 4) Periode kemunduran pendidikan Islam, yaitu sejak jatuhnya Bagdad sampai jatuhnya Mesir ke tangan Napoleon, yang ditandai dengan runtuhnya sendisendi kebudayaan Islam dan berpindahnya pusat-pusat pengembangan kebudayaan ke dunia Barat; dan 5) Periode pembaruan pendidikan Islam, yang berlangsung sejak pendudukan Mesir oleh Napoleon sampai masa kini, yang ditandai gejala-gejala kebangkitan kembali umat dan kebudayaan Islam (Zuhairini, 1986, p. 13).

Dalam konteks pendidikan Islam, peradaban Spanyol Islam telah banyak melahirkan tokoh-tokoh ilmuwan Islam yang mempunyai reputasi yang tidak kalah masyhurnya dengan tokoh-tokoh ilmuwan dunia Islam Timur yang kala itu berpusat di Baghdad. Sebut saja misalnya Ibn Bajah, Ibn Thufail, Ibn Rusyd yang dikenal tidak hanya sebagai tokoh filsafat melainkan juga kedokteran. Begitu juga Ibn Zuhr 
dan al-Zahrawi yang dikenal sebagai peonir ilmu kedokteran, al-Syatibi sebagai ahli ushul fiqh, al-Qurtubi sebagai ahli tafsir dan fiqh, Ibn 'Arabi sebagai tokoh sufi, dan seterusnya (Philip K. Hitti, 2005, p.736), ('Abd al-Rahman al-Nahlawi, 2004, p.23-24).

Sayangnya, kebanyakan referensi sejarah Andalusia, terutama yang ditulis oleh sejarawan Indonesia memandang kejayaan intelektual di Andalusia hanya dicapai di masa Umayyah II, padahal dinasti ini runtuh dan kehilangan penerusnya di masa-masa disintegrasi yang menyebabkan berbagai wilayah Andalusia memisahkan diri dari pemerintahan pusat untuk kemudian membentuk sebuah kerajaan seperti Granada, Sevilla, Toledo, dan seterusnya yang kemudian dikenal dengan Muluk al-Thawaif. Geliat pendidikan dan keilmuan baru mancul kembali dua abad berikutnya, yakni di masa wilayah Andalusia dikuasai oleh dinasti al-Muwahhidun, yang mampu melahirkan tokoh-tokoh ilmuwan besar seperti Ibn Thufail, Ibn Rusyd, Al-Syathibi, al-Qurthubi, Ibn 'Arabi dan seterusnya.

So, penelitian ini akan memberi tawaran kajian historis tentang geliat pendidikan dan keilmuan di masa Spanyol Islam dengan membaginya menjadi dua periode: pertama, masa kekuasan dinasti Umayyah II (tahun 756-1031). Hal ini pun sebenarnya mencapai puncaknya di masa kedua khalifahnya yang terkenal, yakni Abd alRahman III dan putranya al-Hakam II. Sepeninggal al-Hakam II, geliat pendidikan dan keilmuan berangsur-angsur menurun dan bahkan mati sama sekali. Periode kedua (1078-1235), di masa pemerintahan dinasti al-Muwahhidun (1078-1214). Hal ini mencapai puncaknya di bawah pemerintahan khalifah Abu Ya'qub Yusuf al-Manshur (w. 580 H./1184 M). Geliat pendidikan dan keilmuan pasca runtuhnya dinasti ini dan digantikan oleh dinasti Nashriyah (1232-1492 M.) yang lebih dikenal dengan bani Ahmar tidak mengalami kemajuan berarti meskipun juga tidak bisa dikatakan mundur sama sekali. Ada beberapa tokoh ilmuwan yang muncul menghiasi kekhalifahan Granada, di antaranya sejarawan Ibn Bathutahah (1304-1377 M.) dan ibn Khaldun al-Isybili (1332-1406 M.).

\section{Pendidikan dan Kemajuan Intelektual di Spanyol Islam Masa Umayyah II (Tahun 756-1031 M.)}

Pendidikan dan kemajuan intelektual pada periode I di Spanyol Islam, yakni pada masa kekuasan dinasti Umayyah II (tahun 756-1031 M.) secara umum tidak bisa dilepaskan begitu saja dari karakter umum yang melekat pada bani Umayyah yang secara sosial mempunyai status yang relatif tinggi dan terhormat dalam struktur masyarakat Arab sejak zaman pra-Islam karena sebagai pedagang yang kaya raya 
menikmati kekayaan yang melimpah, di tambah lagi dengan posisi yang dicapai oleh Abu Sufyan ibn Harb cucu dari Umayyah sebagai kepala suku Quraisy, menggantikan Abu Jahal (572-624 M.) setelah tewas terbunuh pada perang Badar, peperangan pertama dalam sejarah Islam antara kaum muslimin dan kafir Quraisy, yang terjadi pada tahun ke 2 Hijriyah atau $572 \mathrm{M}$.

Dinasti Umayyah didirikan oleh Mu'awiyah ibn Abi Sufyan ibn Harb ibn Umayyah ibn Abdu Syams ibn Abdu Manaf. Meskipun secara nasab, masih mempunyai hubungan kekerabatan dengan Nabi Muhammad yang bertemu pada sosok Abdu Manaf. Namun berbeda dengan Nabi Muhammad yang dari keluarga miskin, yakni Abdul Muttalibn ibn Hasyim yang dikenal sebagai dermawan karena bertugas menjamu para Haji yang berziarah ke Ka'bah, Muawiyyah tumbuh dan besar di lingkungan kekuasaan dan kekayaan. Oleh karenanya Muawiyyah dalam posisi puncak karier politiknya, dikenal sebagai tokoh politikus dan negarawan yang ambisius yang dekat dengan dua hal di atas, yakni kekuasaan dan kekayaan (al-mulk wa al-milk). Sehingga secara umum dinasti Umayyah tidak menaruh perhatian pada persoalan pendidikan dan pengajaran, melainkan tercurahkan pada urusan pemerintahan, yakni bagaimana melakukan konsolidasi internal untuk meredam pelbagai pemberontakan dan penaklukan wilayah. Dan secara faktual dinasti Umayyah tercatat sebagai otoritas yang mampu mencapai wilayah teritorial terluas sepanjang sejarah Islam yang tidak pernah dicapai oleh sekian banyak dinasti yang tumbuh sesudahnya, termasuk Abbasiyyah dan Turki Usmani. Wilayah kekuasan dinasti Umayyah membentang dari Afrika Barat dan Spanyol Islam sampai ke Asia Tengah. Sayangnya, keturunan Muawiyah tidak berlanjut dan berhenti pada Muawiyah ibn Yazid (w. 684 M.), cucunya. Ini pun hanya berkuasa tidak genap dari dua bulan. Kekhalifahan Umayyah selanjutnya dipegang oleh sepupunya Marwan ibn Al-Hakam ibn Abu al-'Ash dan keturunannya, dan berlanjut terus sampai kemudian diruntuhkan oleh klan bani al-'Abbas melalui kudeta berdarah di bawah pimpinan Abu al-'Abbas Abdullah al-Saffah (721754 M.) pada tahun 750 M. Dinasti Umayyah berkuasa selama 91 tahun (661-750 M) dengan 14 orang khalifah (Al-Marrakisyi, 2016, p.13).

Pendidikan dan pengajaran di masa Umayyah ini oleh para sejarawan pendidikan disebut sebagai masa inkubasi, masa perintisan. Dan secara umum pemerintahan pusat tidak menaruh perhatian terhadap persoalan pendidikan sehingga kebijakannya dalam dunia pendidikann dikenal sebagai desentralisasi pendidikan. Desentralisasi, karena pemerintahan Umayyah tidak menjangkau urusan pendidikan sampai wilayah-wilayah taklukan. Perhatiannya hanya tercurahkan 
pada pendidikan bagi keluarga kerajaan dan para putra mahkota. Kotakota yang menjadi pusat pendidikan sejak di masa-masa khilafah berkembang secara mandiri, terutama Madinah, Persia, Bashrah, dan Kufah, karena kota-kota tersebut merupakan basis pendukung Ali ibn Abi Thalib dan keluarga besar bani Hasim, yakni al-Abbas yang menjadi oposisi selama dinasti Umayyah berkuasa. Hal ini sedikit banyak berpengaruh pada kondisi dan perkembangan pendidikan di Spanyol Islam pada periode pertama di masa Umayyah (tahun 7561031 M.), tepatnya di masa Abd al-Rahman III yang bergelar al-Nashir yang berkuasa pada tahun 912-961 M.), meskipun secara politik dinasti Umayyah II sudah dimulai sejak Abd al-Raman I yang bergelar al-Dakhil berhasil merebut tahta keemiratan Spanyol Islam yang beribukotakan di Cordova pada tahun 756 M. dan hal ini terus berlanjut selama 173 tahun, yakni ketika Abd al-Rahman III yang bergelar al-Nashir mengumumkan kekhalifan dirinya dan menyebut dirinya sebagai amir al-mu'minin pada tahun 929 M. di saat kekhalifan Baghdad tengah mengalami konflik internal di masa khalifah alMuqtadir (908-932 M.), sehingga di dunia Islam terdapat tiga orang khalifah: 'Ubaidullah (909 M) khalifah Fatimiyyah di Kairo, al-Muqtadir di Baghdad dan Abd al-Rahman III di Kordova (Philip, 2005, p.596).

Selama keemiratan di Spanyol Islam, pendidikan dan pengajaran tidak mengalami kemajuan yang berarti, meskipun begitu Abd al-Rahman I sudah mulai merintis membangun infrastruktur berupa masjid Cordova yang megah. Sayangnya fasilitas ini belum dimanfaatkan secara optimal untuk kepentingan pendidikan dan pengajaran bahkan oleh penerus-penerus Abd al-Rahman I yang bergelar al-dakhil ini.

Geliat pendidikan dan pengajaran di Spanyol Islam mencapai puncaknya di masa Abd al-Rahman III yang bergelar al-Nashir dan putranya al-Hakam II (961-976 M.), bahkan kepemimpinan kedua khalifah Umayyah ini menandai puncak kejayaan muslim di Barat. Sebelum dan sesudah periode ini, Spanyol Islam dipandang tidak pernah mampu menggenggam pengaruh politik sedemikian rupa, baik di Eropa maupun diAfrika.

Selama periode ini, ibukota dinasti Umayyah di Andalusia Cordova, menjadi kota paling berbudaya di Eropa dan bersama Konstantinopel dan Baghdad menjadi salah satu dari tiga pusat kebudayaan di dunia. Dengan 130.000 rumah penduduk, 21 kota pinggiran, 73 perpustakaan dan sejumlah besar toko buku, masjid, dan istana, Umayyah memperoleh popularitas internasional.

Khalifah Al-Hakam II, penggantinya abdal-Rahman III, adalah pecinta ilmu pengetahuan, beliau adalah seorang sarjana yang sangat 
mendukung kemajuan ilmu pengetahuan. Al-Hakam II dikenal sebagai khalifah yang banyak memberikan hadiah kepada para sarjana dan mendirikaan 27 sekolah gratis di ibukota (Ibn al-Fardli, 2008, p.37). Di bawah pemerintahannya, didirikan universitas Cordova di masjid Agung Kordova yang didirikan oleh Abd al-Rahman I, yang dilengkapi perpustakaan yang sangat besar. Konon perpustakaan ini menampung 400.000 judul buku. Universitas Cordova dalam perjalannya mampu berkembang dan mengungguli universitas-universitas lain di dunia, seperti universitas al-Azhar di Mesir dan Nizamiyyah di Baghdad. Universitas Cordova menjadi destinasi bagi para mahasiswa dan pecinta ilmu pengetahuan, tidak hanya yang beragama Islam, melainkan juga yang beragama Yahudi maupun Kristen, baik yang berasal dari Spanyol, maupun dari wilayah-wilayah lain di Eropa, Afrika dan Asia. Al-Hakam memperluas bangunan masjid Cordova dan menghiasi masjid dengan mozaik-mozaik yang dibawa oleh para seniman Bizantium. Beliau mengundang para professor dari Timur ke universitas Cordova dan menyiapkan anggaran untuk gaji mereka. Di antara para professor itu adalah Abu Ali al-Qali al-Baghdadi, seorang ahli bahasa dan sastra, penulis al-Amali (w. $356 \mathrm{H}$ ) yang saat ditanya oleh al-Hakam II, perihal siapa ahli bahasa di Andalusia. Beliau menjawab ibn al-Quthiyyah (w. $977 \mathrm{M}$ ) seorang sejarawan yang ahli dalam bidang tata bahasa dan filologi Andalusia.

Sepeninggal al-Hakam II, pendidikan dan pengajaran terus mengalami kemunduran sampai jatuhnya dinasti Umayyah II pada tahun 1031 M. dengan khalifah terakhirnya Hisyam III ibn Abd alRahman IV (1027-1031 M) dengan dihapuskannya kekhalifan Umayyah sama sekali.

\section{Institusi Pendidikan Dasar dan Para Tokohnya}

Masa Spanyol Islam mengenal dua institusi formal yang menjalankan aktifitas pendidikan dan pengajaran, yakni pertama, $K u t t a b$ yang berfungsi sebagai lembaga dasar, yang mengajarkan bahasa dan sastra Arab, di samping ilmu agama, terutama Fikih untuk memenuhi kebutuhan amaliah keagamaan sehari-hari. Bahkan, lembaga ini juga mengajarkan kesenian dan musik.

\section{Bahasa dan Sastra Arab}

Bahasa Arab masuk ke Spanyol Islam bersamaan dengan masuknya Islam di wilayah itu. Sejalan dengan kemajuanyang dicapai oleh umat Islam bahasa Arab dipelajari oleh berbagai lapisan masyarakat di Andalusia, sehingga menggeser peran bahasa local dan menembus batas-batas keagamaan. Kemenangan bahasa Arab atas 
bahasa penduduk asli wilayah taklukan, menurut K. Hitti didahului oleh kemenangan bangsa Arab dalam bidang kemiliteran, politik dan agama. Sebelum menjadi bahasa pergaulan sehari-hari, bahasa Arab terlebih dulu mencapai kemenangan sebagai bahasa ilmu pengetahuan. Lebih dari itu, bahasa Arab pada permulaan abad ke-9 M. sudah menjadi bahasa resmi di Andalusia. Pada waktu itu, seorang pendeta merasa perlu menerjemahkan Taurat kedalam bahasa Arab, karena hanya bahasa Arab yang dapat dimengerti oleh murid-muridnya untuk memahami kitab Suci agama mereka. Hal yang sama terjadi pula di Cordova dan Toledo, sampai Alfonso VI menguasai Toledo tahun 1065 M. menurut al-Siba'i, tidak jarang daripenduduk setempat yang beragama Nasrani lebih fasih berbahasa Arab dari pada sebagaian orang Arab sendiri (Mushtafa al-Siba'i, 1999).

Tokoh bahasa Arab Andalusia pada periode ini adalah Ali alQali, beliau dibesarkan dan menalami beragam ilmu, basaha, sastra, nahwu, sharaf dan ilmu hadits dari ulama-ulama terkenal di Baghdad. Atas undangan khalifah al-Nashir pada tahun 941 M. tida di Cordova, lalu menetap dan mengembangkan ilmunya sampai wafat pada tahun 969 M. karya-karyanya yang tetap abadi dikenang adalah al-Amali dan al-Nawadir.

Ulama lain yang hidup sezaman dengan al-Qali adalah Abu Bakar Muhammad ibn Umar yang dikenal dengan ibn al-Quthiyah (w. 977), seorang ahli bahasa bahasa, penyair dan sejarawan. Beliau berguru pada Abu Bakar Muhammad ibn al-Hasan al-Zabidi al-Isybili (928-989 M.) seorang ulama Nahwu dan bahasa Arab yang dikenal sebagai pengarang buku Thabaqat al-Nahwiyyin wa al-Lughawiyyin dan Mukhtashar Kibat al'Ain. Sebagaimana yang disebutkan Ahmad Amin, masih banyak lagi tokoh-tokoh bahasa yang mempunyai peranan yang cukup penting dalam mengembangkan bahasa Arab di Andalusia (Ahmad Amin, 1969, p.82-84.).

Mengiringi perkembangan bahasa Arab, sastra dan kesusastraan Arab juga berkembang. Di antara sastrawan terkemuka di Andalusia pada periode ini adalah Abu Amr Ahmad ibn Muhammad ibn Abdi Rabbih al-Andalusi al-Qurthubi, lahir di Cordova tahun 860 dan meninggal tahun $940 \mathrm{M}$. Ia menekuni ilmu kedokteran dan musik, meskipun kecenderungannya lebih banyak kepada sastra dan sejarah. Beliau menikmati kedekatan yang sangat dengan beberapa khalifah Umayyah di Andalusia karena gubahan syair-syair pujian kepada mereka, sehingga memperoleh kedudukan terhormat di istana. Pada masa al-Nashir ia menggubah 400 bait syair dengan menggunakan bahan acuan sejarah. Ketika memasuki usia lanjut, ia menyesali kehidupan di masa mudanya, dan lebih memilih kehidupan zuhud. Oleh karenanya ia menggubah syair-syair zuhdiyyat yang dihimpun dalam 
karya al-mumhishat, sedangkan yang berupa prosa ia kumpulkan dan buku al-'Iqd al-Farid.

Sastrawan lain yang tidak kalah popular adalah Abu Amir Abdullah ibn Syuhaid, lahirdi Cordova 992 M., sejak muda sudah dikenal dekat dengan penguasa, bahkan dalam situasi Cordova dilanda kemelut politik, ia tetap mendekat kepada khalifah yang sedang berkuasa. Akan tetapi orang-orang yang tidak suka dengannya selalu berupaya mengingkirkannya dengan menjelek-jelekkan namanya di depan penguasa. Pasca runtuhnya Umayyah, ibn Syuhaid dipenjara oleh otoritas Hamudiyyah dan menerima penghinaan serta penganiayaan yang berat, kemudian dibebaskan dalam keadan lumpuh sampai meninggal pada tahun 1035 M. beberapa karya ibn Syuhaid yang terkenal, di antaranya Risalah al-Thawabi' wa al-Zawabigh, Kasyf al-Dakk wa Atsar al-Syakk, dan Hanut al-'Athr.

Sastrawan lain yang semasa dengan ibn Syuhaid adalah Abu Muhammad Ali ibn Hazm al-Andalusi (994-1064 M). dikenal sebagai salah satu tokoh ulama besar di Andalusia yang tidak hanya mahir dalam bidang sastra, penyair, melainkan juga teolog dan ahli hadis dan faqih. Puisi-puisinya dihimpun dalam sebuah karya sastra Thuq alHamamah. Kedua sastrawan terkemuka itu sempat menyaksikan keruntuhan khilafah Umayyah dan meratapi istana Cordova al-Zahra ketika dilanda kehancuran. Karya ibn Hazm yang terkenal lainnya adalah al-Fashl fi al-Milal wa al-Ahwa' $w$ al-Nihal.

Selain penyair dan sastrawan yang disebut di atas masih banyak lagi tokoh-tokoh penyair yang turut serta menyemarakkan geliat kesusasteraan di Spanyol Islam pada periode Umayyah ini, di antaranya Abu al-Qasim Muhammad ibn ibn Hani ibn Sa'dun al-Isybili al-Andalusi (936-973 M), Abu Abdillah Muhammad ibn Abdillah ibn Isa ibn Abi Zamanain (936-1009 M.), Ja'far ibn Utsman al Mushhafi (w. 983 M) yang di masa al-Nashir diangkat sebagai pengasuh putra mahkotanya al-Hakam II yang kemudian dijadikannya sebagai sekretaris pribandinya, juga Abu Marwan Abdal-Malik ibn Idris al-Jaziri (w. 1003 M.), Ahmad ibn Muhammad ibn Ahmad ibn Sulaiman ibn Isa ibn Darraj al-Qisthili (958-1030 M), Ibn Burd al-Ashghar al-Andalusi (w. 1003), Abu al-Walid Ahmad ibn Abdillah ibn Zaidun al-Makhzumi al-Andalusi al-Qurthubi (1003-1071 M.) yang melejit nama di masa Muluk al-Thawaif, karena di usia 28 tahun iamenyaksikan eksistensi dinasti Umayyah di Cordova, dan selama 40 tahun berikutnya hidup di masa Muluk al-Thawaif dan dipandang sebagi penyair terbesar pada masanya (Taufiq Sulthan al-Yuzbiki, 2010).

\section{Fiqih}

Secara umum para penuntut ilmu di sekolah-sekolah kuttab 
yang tersebar di wilayah Andalusia mendapatkan pelajaran yang cukup lengkap dari para guru yang merupakan ulama-ulama yang ahli di bidanganya, sehingga mereka lebih cepat menyerap ilmu pengetahuan yang dipelajarinya, adalah yang menumbuh kembangkan semangat belajar di masa itu.

Dalam bidang Fiqih, penduduk Andalusia bermazhab Maliki. Konon yang memperkenalkan mazhab Maliki pertama kali di Andalusia adalah Ziyad ibn Abd al-Rahman ibn Ziyad al-Lakhmi di masa Hisyam I ibn Abd al-Rahman al-Dakhil. Ziyad al-Lakhmi dari Cordova (w. 193 H.) belajar ilmu fiqih kepada Anas ibn Malik (715-795 M) di Madinah. Jejaknya kemudian diikuti oleh muridnya bernama Yahya ibn Yahya alLaitsi (152-234 H.) adalah seorang faqih di Andalusia, yang selain memperoleh ilmu dari gurunya al-Lakhmi, ia juga berguru kepada imam Malik. Atas usaha al-Laitsi ajaran fiqih Malikiyyah semakin tersebar di Andalusia dan menjadi anutan oleh sebagaian besar umat Islam di sana, yang sebelumnya mereka adalah penganut fiqih alAwza'i (88-157H./707-776 M.), seorang ulama fiqih besar yang ajarannya tersebar di wilayah Syam pada masa kejayaan dinasti Umyyah di Damaskus.

Tokoh lain yang tidak kalah peranannya di dalam mengembangkan ilmu fiqih di Andalusia adalah seorang sastrawan Abu Bakar Muhammad ibn Marwan ibn Zuhr (w. 1031 M.), di samping Abu Muhammad Ali ibn Hazm al-Andalusi pengarang buku al-fashl fi alMilal wa al-Ahwa wa al-Nihal. Semula ibn Hazm adalah penganut mazhab al-Syafi'i, tetapi kemudian beralih mengikuti mazhab Dawud al-Zhahiri, yang oleh karenanya telah banyak berperan di dalam menyebarkan kedua mazhab fiqih di wilayah Andalusia.

Dasar pemikiran fiqih mazhab Maliki adalah hadis yang terangkum dalam kita al-Muwaththa yang memuat sekitar 7000 hadis Nabi, adalah karya besar imam Malik ibn Anas yang sekaligus meupakan kitab fiqih mazhab Maliki. Oleh sebab itu perhatian kaum muslimin Andalusia terhadap hadis juga sedemikian besar. Penghafal hadis yang terkenal di Andalusia adalah Abu Abd al-Rahman ibn Mukhallad al-Qurthubi (817-889 M.) yang belajar dari para imam dan ahli hadis di Timur. Selain ibn Mukhallad, tercatat juga sebagai imam dan ahli hadis yang terkenal di masanya adalah Abu Muhammad Qasim ibn Ashbagh al-Bayani (244-340 H.), Muhammad ibn Abd alMalik ibn Aiman al-Qurthubi (w. 330 H.) dan seterusnya (Livi Profensal, 1979, p.59).

\section{Kesenian dan Musik}

Kesenian dan music mengambil bagian yang cukup penting di lembaga pendidikan kuttab. Hal ini disebabkan karena masyarakat 
Spanyol adalah penggemar berat musik. Dengan masuknya peradaban Arab Islam ke wilayah Spanyo Islam meniscayakan pertumbuhan kesenian dan musik Arab dan Latin secara beriringan yang menciptakan harmoni yangkhas Andalusia. Musik jenis ini dipopulerkan oleh Abu al-Hasan ibn Nafi yang dijuluki sebagai Ziryab (857-789 M.) adalah pemusik dan penyanyi kenamaan yang hidup di era Abbasiyyah di masa Harun al-Rasyid, beliaulah yang berjasa membawa jenis music Arab ke Andalusia, bahkan ke Eropa sehingga dikenal secara mendunia. Ziryab tidak hanya dikenal melalui suaranya emasnya, melainkan juga sebagai seniman, penyair, sastrawan dan astronom, Setelah hijrah ke Andalusia dan menetap di Cordova, Ziryab selalu tampil dalam even-even kenegaraan. Kepiawaiannya bermain musik dan seni membuatnya menjadi termasyhur di kala itu, sehingga dikenang sebagai legenda.

Ilmu dan kemahirannya dalam kesenian danmusik dijarkannya kepada seluruh lapisan masyarakat, baik laki-laki dan perempuan, merdeka maupun para mudak dan hamba sahaya, baik secara formal di lembaga-lembaga kuttab, maupun secara informal.

Lebih dari itu, saking senangnya sang khalifah terhadap kepiawaian Zaryab, khalifah membangun sebuah sekolah khusus yang mempelajari musik bernama Dar al-Madaniyyat, yang merupakan lembaga music pertama di Andalusia dan Zaryab sebagai direkturnya. Zaryab merekrut putra-ptrinya dan para budaknya sebagai guru-guru di sekolah ini. Kurikulum yang digunakan mencakup semua jenis alat music (al-'azb), melodi (al-ghina), dan syair lagu (al-talhin), syair, dan menari. Lembaga ini mendapatkan antusiasme dan perhatian yang cukup besar dari semua lapisan masyarakat Andalusia, bahkan sampai menembus ke luar Andulusia dan Eropa secara keseluruhan.

\section{Pengajaran di Pendidikan Tinggi dan Para Tokohnya}

Pendidikan Tinggi yang dikenal sebagai universitas merupakan pendidikan lanjutan tingkat tinggi, yang tentu muatan kurikulumnya tidak seperti yang diajarkan di sekolah kuttab. Kurikulum di perguruan tinggi di Andalusia mencakup seluruh bidang atau disiplin keilmuan, agama, teologi, filsafat, kedokteran, sains, dan sejarah. Pendidikan Tinggi inilah yang dalam perkembangannya melahirkan tokoh-tokoh ilmuan besar yang tidak hanya dikenal secara local di Andalusia, melainkan juga dikenal secara mendunia, baik di Timur dan Barat. Pada sub bab ini akan dibahas beberapa disiplin ilmu saja yang merupakan grand topic di universitas di Andalusia.

\section{Agama}

Sebagaimana yang dijelaskan dalam pembahasan terdahulu, 
agama juga menjadi bagaian yang cukup penting dalam pendidikan dan pengajaran di lembaga Kuttab, terutama fiqih atau ilmu fiqih yang merupakan ajaran dasar bagi ibadah ritual keberagamaan dan amaliah sehari-hari. Di lembaga Tinggi Universitas, agama juga menjadi dasar bagi bangunan keilmuan di Perguruan Tinggi. Ilmu-ilmu agama yang dimaksudkan dalam konteks ini meliputi Fiqih, Tafsir, Hadis dan Qira'at.

Ilmu agama yang berkembang cukup pesat adalah ilmu Qiraat, yaitu ilmu yang membahas cara membaca lafazh-lafazh Alquran yang baik dan benar sesuai riwayat-riwayat yang valid. Ilmu Qiroat ini menjadi materi dasar ilmu alquran dan Tafsir. Di antara tokoh dalam bidang ini adalah Abu 'Amru al-Dani yang dikenal dengan ibn alShairafi (371-444 H.) yang tidak hanya dikenal sebagai ahli dalam Qiraat, juga seorang ahli hadis dan tafsir.

\section{Teologi, Filsafat dan Sains}

Filsafat merupakan salah satu disiplin ilmu yang sudah dikenal sejak zaman al-Nashir dan berkembang pesat di masa putranya alMustanshir. Tokoh filsuf pertama yang menekuni filsafat adalah Muhammad ibn Abdillah ibn Masarrah al-Qurthubi (886-931 M.), yang dikenal sebagai Ibn Masarrah. Dikenal sebagai seorang sufi, teolog dan filsuf sekaligus (Luthfi Abd al-Badi', 1989, p. 44)(Ibn al-Fardli, 1966).

Di masa-masa ini banyak pelajar-pelajar Andalusia yang pergi mengembara ke wilayah Timur seperti Mesir, Bashrah, Kufah, Baghdad, dan Damaskus untuk mendalami berbagai disiplin ilmu agama: hadis, tafsir, fiqih, logika dan filsafat. Misalnya Muhammad ibn 'Abdun al-Jabali al-Andalusi (952 M.) yang dikenal sebagai ahli kedokteran dan matematika yang pergi Bashrah dan Mesir untuk belajar logika dan filsafat secara langsung kepada seorang filsuf Abu Sulaiman Muhammad ibn Thahir ibn Bahram al-Sajestani (w. 990 M.) di , lalu kembali ke Cordova dan mengabdi pada khalifah al-Mustanshir dan putra Hisyam al-Muayyad billah. Begitu juga Abu al-Qasim Maslamah ibn Ahmad al-Majrithi (w. 1007 M.) juga pergi ke wilayah Timur untuk mempelajari manuskrip-manuskrip Arab dan Yunani, kemudian kembali ke Andalusia dan mendirikan sekolah Astronomi dan Matematika, sehingga dikenal sebagai orang yang paling berjasa dalam menyebarkan matematika, astromi, kimia dan kedokteran di Andalusia bahkan di Eropa. Dua bukunya Ghayat al-Hakim dan Ratbat al-Hakim diterjemahkan de dalam bahasa Latin atas permintaan raja Alfonso X, bahkan al-Majrithi dipandang sebagai tokoh yang memperkenal pemikiran Ikhwan al-Shafa ke Eropa melalui muridmuridnya di antaranya al-Karmani (w. 1063 M.)( Luthfi, 1989).

Selain al-Majrithi yang dikenal sebagai ahli dalam bidang

J-PAI : Jurnal Pendidikan Agama Islam

Vol. 4 No. 1 Juli-Desember 2017 
astronomi dan matematika, juga dikenal seorang tokoh legendaris Abu al-Qasim 'Abbas ibn Firnas al-Takurini (810-887 M) adalah fisikawan, kimiawan, teknisi, musisi dan penyair Andalusia. Percobabaanpercobaannya yang spektakuler telah membuat masyarat Andalusia tercengang. Di antara penemuannya adalah kacamata, pena, sayap terbang yang menjadi dasar bagi teknologi penerbangan modern (Abbas ibn Firnas).

\section{Kedokteran dan Farmasi}

Perkembangan yang cukup bergeliat dalam bidang kimia dan matematika, sedidikit banyak berpengaruh dalam dunia kedokteran dan farmasi. Ilmu kimia,baik murni maupun terapan merupakan dasar bagi ilmu farmasi yang tentu berkaitan lansung dengan ilmu kedokteran. Penemuan dan pengembangan dalam bidang farmasi dan kedokteran telah mendorong para ahli untuk menggali dan mengembangkan ilmu kimia dan ilmu tumbuh-tumbuhan untuk kepentingan pengobatan. Oleh karena itu, sebenarnya ulama-ulama Arablah yang menciptakan apotek dan farmasi.

Kedokteran termasuk cabang disiplin ilmu yang berkembang di Andalusia sejak masih merupakan wilayah keemiratan dan dipelajari perguruan tinggi di masa kekhalifahan al-Nashir, sebut saja Abu alQasim al-Zahrawi (936-1013 M.) ahli kedokteran kelahiran Madinat alZahra ini dikenaldi Eropa dengan Albucasis yang terkenal sebagai ahli bedah, perintis ilmu penyakit telinga dan pelopor ilmu penyakit kulit. Karyanya yang berjudul al-Tashrif li Man 'Ajaza 'an al-Ta'lif dipandang sebagai insklopedi kedokteran, terdiri dari 30 jilid telah diterjemahkan ke dalam bahasa Latin pada abad ke-12 oleh Gerardo al-Karimuni (Gerard Cremona) dan dicetak ulang di Genoa (1497 M.), di Basle (1541 M.), dan di Oxford (1778 M) dan dijadikan sebagai referensi pokok dalam dunia kedokteran di universitas-universitas Eropa selama lima abad di abad pertengahan. Penemuannya terhadap alat-alat kedokteran mempunyai pengaruh besar terhadap ilmu kedokteran Eropa hingga kini (Hitti, 2005).

\section{Sejarah}

Perhatian umat Islam di Andalusia terhadap sejarah juga cukup besar. Hal ini lahir dari semangat mempelajari hadis Nabi Muhammad. Aktifitas pengumpulan hadis Nabi melahirkan minat untuk menghimpun kisah-kisah Nabi, para sabahat dan seterusnya. Tradisi ini dalam perkembangannya melahirkan upaya dalam menulis sejarah secara lebih luas. Sejarawan Andalusia terkemuka di masa awal di antaranya adalah Abd al-Malik ibn Habib al-Murdasi al-Silmi (790-853 M.). Tokoh kelahiran Toledo ini dikenal di samping seorang sejarawan, adalah juga seorang penyair yang juga ahli dalam ilmu Nahwu dan 
Arudl. Mula-mula tinggal di Cordova, kemudian pergi ke wilayah Timur untuk mempelajari ilmu Hadis, Fiqih, bahasa dan Nahwu kemudian kembali lagi ke Andalusia. Al-Murdasi menulis dalam berbagai bidang ilmu: Fiqih, bahasa, kedokteran dan sejarah, yang salah satu bukunya berjudul Kitab fi Fath al-Andalus dan al-Ghayah wa al-Nihayah.

Sejarawan lainnya yang terkenal di antaranya Yahya ibn alHakam al-Ghazzal (790-866 M.) dikenal juga sebagai seorang penyair yang karena keindahan gubahan syairnya dijuluki al-Ghazzal. Tokoh yang dekat dengan Abd al-Rahman al-Awsath ini sering ditugasi sebagai duta, misalnya ke imperium Bizantium dan Normadia daerah Skandinafia untuk tujuan perdamaian dan persahabatan. Setelah itu muncul Abu Bakar Muhammad ibn Umar al-Quthiyyah (w.977 M.), tokoh yang hidup di masa kejayaan Umayyah II ini menulis sejarah Andalusia dalam karyanya Tarikh Iftitah al-Andalus. Tulisannya yang detail menjadikannya buku yang istemewa karena analisisnya terhadap peristiwa-peristiwa di Spanyo Islam yang sebelumnya tidak diketahui oleh orang Arab, yang mencakup penaklukkan Andalusia sampai masa pemerintahan Abd al-Rahman al-Nashir. Menyusul kemudian 'Uraib ibn Sa'id al-Qurthubi (w. 980 M.) seorang muwallad, karena moyangnya seorang Nasrani Cordova yang sudah masuk Islam. Tokoh yang dikenal dengan beberapa khalifah Umayyah II ini - dari alNashir, al-Mustanshir dan al-Hajib al-Manshur - meringkas buku Tarikh al-Thabari dalam bukunya Ikhtishar Tarikh al-Tabari dan menambahkan bab yang membahas khusus tentang Afrika dan Andalusia, disamping memberi catatan indeks pada buku tersebut, serta bukunya yang lain Taqwim Qurthubah.

Sejarawan lain yang tidak kalah terkenalnya adalah Hayyan ibn Khallaf ibn Hayyan al-Qurthubi (987-1076 M). ia adalah sastrwan kenamaan di samping dikenal sebagai sejarawan besar pada masanya. Gaya penulisan sejarahnya sangat khas yang tidak berdasarkan tansmisi lisan sebagaimana sejarawan lain, melainkan bersandar pada kutipan dari buku-buku yang sudah ada, sehingga tidak jarang ibn Hayyan menulis "sebagaimana yang saya baca dalam buku Fulan...". Bukunya dalam sejarah yang masih dikenal adalah al-Muqtabis fi Tarikh al-Andalus, yang menkaji tentang penaklukan Andalusia sampai masa pemerintahan al-Mustanshir, di samping bukunya yang lain $\mathrm{Al}$ Matin yang membahas peristiwa pemberontakan suku Berber sampai jatuhnya Cordova.

Penulis biografi terkenal di periode ini adalah Abual-Walid Abdullah ibn Muhammad yang dikenal dengan ibn al-Fardli alQurthubi (962-1013 M.), dikenal sebagai Qadli di Valensia sampai akir hayatnya. Karier akademiknya dimulai ketika mengembara ke wilayah 
Timur untuk menuntut ilmu di Makkah, Mesir dan Qairuwan kemudian kembali ke Andalusia dan mengabdkan diri pada pemerintahan Muhammad al-Mahdi. Karya-karyanya sekitar biografi di antaranya, Tarikh Ulama al-Andalus; al-Mu'talaf wa al-Mukhtalaf fi Asma al-Rijal; Akhbar Syu'ara al-Andalus dan seterusnya. Bukunya Tarikh 'Ulama alAndalus disempurnakan oleh sejarawan yang datang sesudahnya, yakni ibn Basykuwal al-Qasim Khalaf ibn Abd al-Malik al-Andalusi alQurthubi (1101-1183 M) murid Ibn Rusyd sang filsuf (1058-1126 M.), dengan judul Kitab al-Shilah fi Tarikh Aimmat al-Andalus yang diterbitkan pada tahun 1139, dan disempurnakan lagi oleh Abu Abdillah Muhammad ibn al-Abrar (1199-1260 M.) dengan judul alTakmilah li Kitab al-Shilah.

Masih banyak lagi sejarawan yang terkenal di masa Umayyah II ini, misalnya tokoh seperti Ibn Abd Rabbih (869-940 M.) dengan karyanya al-'Iqd al-Farid, sebuah karya yang mencakup berbagai disiplin ilmu: sejarah, silsilah dan nasab, kata-kata mutiara, syair, arudl dan musik. Berikutnya adalah ibn Hazm al-Andalusi al-Qurthubi (9941064 M.) dengan karyanya yang hingga kini masih dikenal al-Fashl fi al-Milal wa al-Ahwa wa al-Nihal, yang sudah banyak dibicarakan pada pembahasan terdahulu (al-Hajji, 1981, p. 314).

Tokoh penting sejarawan yang tidak dapat diabaikan adalah Abu al-Qasim Sha'id al-Andulusi (1029-1070 M.) karyanya yang saangat monumental Thabaqat al-Umam menjdai rujukan bagi sejarwan-sejarwan yang datang kemudian seperti al-Qifti (1172-1248 M.) dari Mesir, penulis buku Akhbar al-'Ulama bi Akhbar al-Hukama yang dikenal sebagai Tarikh al-Hukama, ibn Abi 'Ushaibi'ah (12001270 M.) dari Kairo Mesir, pengarang kitab 'Uyun al-Anba fi Thabaqat $a l-A t h i b b a$, dan lainnya. Sha'id pernah menjabat sebagai pemimpin kantor pengadilan Toledo dan mengembangkan keilmuannya sebagai seorang ahli sejarah, matematika dan astronomi. Dan masih banyak lagi tokoh-tokoh lain yang tidak hanya menguasi dalam satu bidang ilmu pengetahuan saja, melainkan juga ahli dalam berbagai cabang ilmu. Seorang filsuf misalnya dalam waktu yang sama juga ahli dalam ilmu kedokteran, astronomi, kimia, sastra, music dan lainnya. Maka, tokoh sejarawan secara bersamaan bias dikenal sebagai ahli bahasa, teologi, filsafat, kedokteran dan seterusnya. Hal ini disebabkan tidak hanya oleh sekolah kuttab dan perguruan tinggi saja, melainkan masih kentalnya tradisi sorogan (al-qira'ah ala al-syeikh) pada guru atau ahli yang dikenal sangat mumpuni di bidangnya yang di samping mengajar di perguruan tinggi yang tersebar di Andalusia juga di wilayah-wilayah Timur, mereka juga membuka halaqah-halaqah kecil secara mandiri di masjid-mesjid kota di wilayah yang mereka tinggali atau mendirikan 
lembaga pendidikan dan laboratorium peneltian sendiri .

Prestasi umat Islam di dalam memajukan ilmu pengetahuan tidaklah diperoleh secara kebetulan, melainkan dengan kerja keras melalui beberapa tahapan pembangunan: pertama: dilakukan penerjemahan buku-buku klasik Yunani, Persia, dan India, dalam berbagai bidang kedokteran, kimia, astronomi, filsafat dan lainnya, kemudian disusul pensyarahan dan komentar terhadap terjemahanterjemahan tersebut. Setelah itu dilakukan koreksi terhadap teori-teori yang sudah ada, yang seringkali melahirkan teori baru sebagai hasil renungan pemikir-pemikir muslim sendiri. Oleh karena itu, umat Islam tidak hanya berperan sebagai jembatan penghbung bagi warisan budaya lama dari zaman klasik ke zaman baru, melainkan telah erjasa pula menemukan menemukan teori-teori baru. Telah cukup banyak teori orisinil mereka, yang mempunyai arti besar dalam pengembangan ilmu pengetahuan modern.

Kedua, pembangunan infrastruktur pendidikan oleh pemerintah berupa sekolah-sekolah kuttab yang jumlahnya cukup fantastis, yakni 800 sekolah dan 72 perguruan tinggi yang tersebar di pusat ibukota dan seluruh wilayah Andalusia. dan dilengkapi dengan pembangunan lebih dari 70 perpustakaan yang mempunyai koleksi buku lebih dari 400.000 judul buku. Lebih dari itu, al-Mustanshir misalnya melakukan ekspedisi besar-besaran yang didanai oleh pemerintah ke pusat-pusat ilmu pengetahuan di wilayah Timur, dari Syam, Persia, Madinah, Baghdad, Kufah, Bashrah, Mesir, Qairuwan dan sebagainya, turut menumbuhkan semangat dan rasa cinta ilmu pengetahuan, terutama pasca kembalinya para penuntut ilmu itu dari pengembaraannya yang panjang ke Andalusia. Mereka tidak jarang mengembangkan keahliannya dengan mengabdikan diri pada pemerintah di lembaga-lembaga pendidikan yang telah ada atau bahkan mendirikan sendiri institusi atau laboratorium untuk mengembangkan eksperimentasi mereka, adalah hal yang menambahgeliat ilmu pengetahuan berkembang pesat di Andalusia.

Andalusia kala itu sudah mencapai tingkat peradaban yang sangat maju, sehingga hampir tidak ada seorang pun dari penduduknya yang buta huruf, di saat orang-orang Kristen Eropa baru mengenal dasar-dasar ilmu pengetahuan. Itu pun terbatas hanya pada beberapa pendeta saja. Dari Andalusia ilmu pengetahuan dan peradaban arab Islam menyebar ke Eropa, melalui pelajar-pelajar dan akademisi yang pernah menuntut ilmu di universitas Cordova, Malaga, Sevilla, Granada atau lembaga-lembaga ilmu pengetahuan lainnya, adalah hal yang menghantarkan Eropa mencapai masa kebangkitan kembali dan pencerahan. 


\section{Pola Pendidikan dan Pengajaran pada Periode II}

Pada periode ke-2, yakni di masa dinasti al-Muhawwidun ini, pola pendidikan dan pengajaran tidak jauh berbeda dengan di masa Umayyah II. Ketokohan Abu Ya'qub Yusuf yang dikenal sebagai pecinta ilmu, mampu mengembangkan tidak hanya insfratruktur pendidikan termasuk dibangunnya masjid agung (al-majid al-kabir) dan bangunanbangunan yang bernilai arsitektur tinggi di Sevilla dan Maroko, melainkan juga mendorong perkembangan ilmu pengetahuan, terutama kedokteran dan filsafat. Khalifah Abu Ya'qub Yusuf inilah yang mengangkat Ibn Thufail (1110-1185 M.) sang filsuf sebagai penasehat pribadinya dan tabib istana, sebuah kombinasi jabatan yang tidak pernah terjadi di sebuah kerajaan Islam. Khalifah ini pulalah yang memerintahkan Ibn Rusyd (1050-1126 M.) untuk membuat komentarkomentar terhadap karya-karya Aristotle sehingga ibn Rusyd dikenal sebagai sang komentator terbesar (al-syarih al-akbar) sepanjang sejarah filsafat Islam (Ibn Rusyd, 1982, p. 5)(Fakhri, 1982, p. 10).

Spanyol Islam dengan ibukota barunya Sevilla, seperti mempunyai magnitnya tersendiri. Kalau di masa Umayyah II, Al-Nashir dan al-Hakam II melakukan ekspedisi-ekspedisi ilmuwan ke wilayah Timur, untuk menunt ilmu dan membeli buku. Maka, di masa alMuwahhidun ini, para ilmuwan Timur yang pergi ke aandalusia untuk mengembangkan ilmu pengetahuannya, terutama pada abad ke-11. Dan arus transmisi ilmu pengetahuan ini mencapai puncaknya yang cukup kuat di abad ke-12. Sehingga, tradisi ilmiah di Timur mengalir melimpai daratan Eropa.

Dalam proses peraliahan ilmu kedokteran dari Arab Timur ke Eropa, wilayah Barat Laut Afrika, yakni Marakesh dan Spanyol, terutama Toledo, tempat Gerald dari Cremona (Jiraldu al-Karimuni) dan Michael Scott (Mikael Skud) bekerja sebagai penerjemah, memainkan peranan yang cukup penting. Gerald telah menerjemahkan karya al-Zahrawi al-Tashrif, karya al-Razi al-Manshur, dan karya Ibn Sina, al-Qanun. Pelopor gerakan penerjemahan dalam bahasa Latin ini terus diikuti oleh nama-nama lain seperti Constantin al-Ifriqi kelahiran Kartago dan Faraj ibn Salim seorang Yahudi dari Sicilia yang menerjemahkan karya al-Razi al-Hawi pada tahun 1279 M., dan karya ibn Jazlah Taqwim al-Abadan. Berkat merekalah ilmu kedokteran dari Arab bisadikenal di benua Eropa.

Dari sini, pola pendidikan dan pengajaran pada masa dinasti alMuwahhidun berupa halaqah di masjid masjid, di lembaga-lembaga pendidikan formal seperti sekolah-sekolah milik pemerintah maupun halaqah-halaqah yang didirikan oleh para tokoh ilmuan yang muncul 
kala itu, baik di anak benua Spanyol yang Sevilla sebagai ibukotanya maupun di Maroko, tepatnya di jami' Hassan di Rabath dan Marakesh dan perguruan tinggi yang sudah berdiri sejak masa Umayyah II di Andalusia yang tersebar di Sevilla, Cordova, Malaga, Granada dan Almeria dan Maroko.

Kurikulum pendidikan dan pengajaran di lembaga-lembaga pendidikan sebagaimana tersebut di atas meliputi ilmu pengetahuan agama dan ilmu pengetahuan umum yang dikenal sebagai sains yang meliputi filsafat, kedokteren, sains, geografi, sejarah, ilmu agama dan lain sebagainya yang secara umum tidak jauh berbeda dengan kurikulum yang diterapkan di lembaga pendidikan dan pengajaran pada masa Umayyah II.

\section{Muatan Kurilulum dan Tokoh-Tokoh Ilmuwan}

Kurikulum pendidikan dan pengajaran di lembaga-lembaga pendidikan sebagaimana tersebut di atas meliputi ilmu pengetahuan agama dan ilmu pengetahuan umum yang dikenal sebagai sains yang meliputi filsafat, kedokteren, sains, geografi, sejarah, ilmu agama dan lain sebagainya yang secara umum tidak jauh berbeda dengan kurikulum yang diterapkan di lembaga pendidikan dan pengajaran pada masa Umayyah II.

\section{Kedokteran}

Keluarga khalifah di masa al-Muwahhidun dikenaal sangat dekat sekali dengan para pelaku kedokteran. Nama Ibn Zuhr sangat berkilau di langit istana al-Muwahhidun, sederajat dengan nama alZahrawi di masa khalifah Abd al-Rahman III dari dinasti Umayyah II. Ibn Zuhr dalam bahasa Latin dikenal sebagai Avenzoar, nama lengkapnya adalah Abu Marwan Abd al-Malik ibn Abi A'la (1094-1162 M.) merupakan anggota paling terhormat dari perhimpunan dokter di Spanyol, meninggal di Sevilla setelah sekian lama mengabikan dirinya sebagai tabib istana yang merangkap sebagai wazir di masa khalifah Abd al-Mu'min pendiri dinasti al-Muwahhidun, ayah dari Abu Ya'qub Yusuf. Orisinalitas pemikirannya terdapat dalam karya-karyanya yang secara khusus membahas tentang kedokteran, tidak seperti temanteman sejawatnya yang lain yang juga menekuni cabang-cabang lain seperti sastra, filsafat, astronomi dan seterusnya. Karyanya yang paling terkenal adalah Al-Taisir fi al-Mudawat wa al-Tadbir.konon karya ini ditulisnya untuk memenuhi permintaan temannya Ibn Rusyd sang failasuf yang menulis dalam bidang kedokteran dalam bukunya $\mathrm{Al}$ Kulliyyat fi-Al-Thib. Ibn Rusyd sangat kagum kepada Ibn Zuhr dan memujinya sebagai tabib terbesar sejak Galinus dari Yunani. Setidaknya Ibn Zuhr ahli klinis terbesar dalam sejaran Islam setelah al- 
Razi (864-923 M.), tokoh saintis yang juga tabib dari Roy Persia adalah kepala rumah sakit di masa khalifah al-Mu'tadlid (892-902 M.) dari Abbasiyyah (Al-Marrakisyi, 2016, p.178).

Keluarga ibn Zuhr melahirkan enam generasi para tabib tanpa pernah terputus. Cucunya yang bernama Abu Bakar Muhammad ibn Abi Marwan ibn Zuhr (1072-1162 M.) yang tidak hanya ahli dalam kedokteran melainkan juga piawai dalam sastra. Ia menguasai semua cabang ilmu sastra. Abu Yusuf Ya'qub al-Manshur mengangkatnya sebagai tabib pribandinya di Maroko, tempat ia wafat karena diracun oleh seorang menteri yang iri kepadanya. Khalifah al-Manshur sendiri menghadiri pemakamannya dan berkhotbah, bahkan salah satu moyang Ibn Zuhr, kakeknya dan penyandang nama Abu Marwan Abdal-Malik telah mengembangkan ilmu kedokteran tidak hanya di Spanyol, melainkan juga di Baghdad, Qairuwan, dan Kairo. Tabib lain dari spanyol yang juga mempraktekan ilmunya di wilayah Timur adalah Ubaidullahibn Muahaffar al-Bahili dari Almeria. Al-Bahili, yang dikenal sebagai penyair dan tabib, mulai mengabdi kepada khalifah Mahmud ibn Maliksyah dari bani Saljuk pada tahun 1127 M di Baghdad, yang memberikan kepadanya sebuah rumah sakit berjalan yang diangkut oleh empat puluh ekor unta, sampai ajal menjemputnya pada tahun 1154 M. di Damaskus.

\section{Filsafat}

Filsafat merupakan disiplin ilmu yang sering dipandang sebagai ikon kemajuan intelektual. Begitu juga yang terjadi di Andalusia, terutama pada periode kebangkitan intelektual ke-2 di wilayah Spanyol Islam. Seakan menjadi trend kala itu bagi seorang ilmuwan, akan dipandang sebagai ilmuwan kalo juga menguasai ilmu warisan Yunani kuno ini. Oleh karenanya, khalifah Abu Ya'qub Yusuf sendiri menaruh perhatian besar terhadap filsafat. beliaulah yang memerintahkan Ibn Rusyd sang filsuf untuk melakukan komentarkomentar terhadap pemikiran filsafat Aristotle, sehingga filsafat menjadi materi penting, terutama di perguruan tinggi di masa alMuwahhidun. Pemikiran filsafat Yunani seperti cahaya yang menerangi kegelapan dunia intelektual Islam di masa itu. Para pengagum filsafat itu kemudian membentuk sebuah mata rantai yang menghubungkan anatara pemikiranYunani dan ajaran Islam. Kontribusi mereka semakin besar ketika mereka berupaya mencari titik temu antara dua kutub pemirian yang berbeda karakter itu. Filsafat mempunyai akar keilmuan positifistik, sementara agama merupakan ajaran yang disimpulkan berdasarkan wahyu. Bagi para pecinta filsafat, Aristotle dianggap benar, Plato juga benar, Alquran juga benar (Hitti, 2005, p. 739). 
Filsafat yang dikembangkan oleh orang Yunani dan agama oleh nabi-nabi Ibrani sama-sama merupakan warisan berharga yang berasal dari dua kutub budaya Barat dan Timur. Berkat para pemikir muslim, baik yangtumbuh dan berkembang di Baghdad maupun di Andalusia, dua arus pemikiran itu bias dipadukan dan dibawa secara harmoni menuju Eropa. Mereka memberikan kontribusi yang sangat besar pada perkembangan peradaban, terutama pada pengembangan ilmu pengetahuan, filsafat dan teologi di masa-masa berikutnya. Limpahan arus intelektual tersebut, terutama filsafat bahkan mampu menumbuhkan gagasan dan pemikiran baru di Eropa dan menjadititik awal kebangkitan kembali "renaissance" dan berakhirnya "zaman kegelapan" di awal abad ke-15 dan 16.

Pemikiran filsafat di Andalusia, sudah dikembangkan oleh tokoh-tokoh seperti Ibn Masarah al-Jabali (883-931 M.) dan Sulaiman Ibn Jabirul al-Andalusi (1021-1070 M.) seorang filsuf Yahudi yang di Eropa dikenal dengan Ben Gabirol sebagai guru besar pertama dalam aliran neo-Platonisme di Barat, sehingga sering disebut sebagai PlatoYahudi. Geliat pemikiran filsafat sempat meredup seiring dengan situasi politik, peperangan dan pergantian penguasa. Cayaha terang pemikiran filsafat mencapai puncaknya di masa dinasti alMuwahhidun. Abad ke-12 dipandang sebagai abad terbesar dalam sejarah pemikiran filsafat Islam di Andalusia.

Para pioneer pemikiran filsafat di masa-masa awal dinasti alMuwahhidun ini, adalah tokoh multi talenta, bernama Abu Bakar Muhammad ibn Yahya ibn Bajjah yang dikenal di Barat sebagai Avenapace (w. 1138 M.), seorang filsuf sufi, ilmuwan astronomi, dokter, musisi, dan komentator filsafat Aristotle. Ibn Bajjah yang lebih tenar dengan julukan Ibn al-Shaigh telah menulis beberapa risalah dalam bidang Astronomi yang mengkritik asumsi-asumsi Ptolemius, dan membuka jalan bagi Ibn Thufail dan al-Bitruji. Risalah-risalah lainnya dalam bidang kedokteran banyak dikutip oleh Ibn al-Baithar (1197-1248 M.) seorang ahli farmasi yang datang setelahnya, dan beberapa karyanya yang lain banyak mempengaruhi pemikiran Ibn Rusyd dalam al-Kulliyyat fi al-Tibb. Karya filsafatnya tertuang dalam risalah Tadbir al-Mutawahhid, yang menggambarkan seorang manusia mampu mencapai akal aktif, setelah melalui tahapan-tahapan penyempurnaan jiwa yang disebutnya sebagai tadbir(Ibn Abi 'Ushaibi'ah, p. 481).

Pemikiran filsafat Ibn Bajjah diteruskan oleh Abu bakar Muhammad ibn Thufail, adalah seorang filsuf illuminasionis yang berupaya mengembangkan filsafat neo-Platonisme Ibn Sina belajar ilmu kedokteran di Granada. Kepiawaiannya dalam kedokteran 
membawanya dekat dengan istana al-Muwahhidun. Khalifah Abu Ya'qub Yusuf menjadikannya sebagai penasehat pribadinya sekaligusmenjabat sebagai kepala tabib istana. Sebelum meninggal di Maroko tahun 1185 M., Ibn Thufail merekomendasikan Ibn Rusyd untuk menggantikan posisinya. Karya besarnya adalah risalah Hayy ibn Yaqzhan, sebuah karya sastra filsafat, yang menggaris bawahi bahwa manusia dengan kemampuan intelektualnya dan ketinggian spiritualitasnya mampu mencapai cahaya Tuhan, sebuah tingkatan illuminasi tertinggi yang dapat dicapai oleh manusia. Hayy ibn Yaqzhan dipandang sebagai cerita filsafat yang paling mengagungkan dalam sejarah sastra di abad pertengahan. Pertama kali diterjemahkan dalam bahasa Latin oleh Edward Pococke tahun 1671 M. sebelum kemudian diterjemahkan ke dalam beberapa bahasa Eropa, Belanda (1672 M.), Rusia (1920 M.), dan Spanyol (1934 M.) yang dianggap telah mengilhami novel terkenal Ribinson Crusoe karya Daniel de Foe. Ibn Thufail meminjam nama tokoh-tokoh kisah dengan judul kisah yang sama karya Ibn Sina, dan hal yang sama juga dilakukan oleh tokoh filsuf Illuminasionis sezaman dengannya al-Suhrawardi (1154-1191 M.).

Pemikirian filsafat mencapai puncaknya di tangan filsuf besar kelahiran Cordova Abu al-Walid Muhammad ibn Muhammad ibn Ahmad ibn Rusyd (1126-1198 M.), yang dipandang mempunyai pengaruh besar terhadap kebangkitan kembali Eropa. Ibn Rusyd tidak hanya dikenal sebagai filsuf dan komentator filsafat Aristotle, melainkan juga ahli dalam bidang astronomi, kedokteran, dan Fiqih. Ibn Rusyd besar dilingkungan terhormat yang menjunjung tinggi keilmuwan,terutama teologi dan fiqih. Pada tahun 1169-1171, Ibn Rusyd diangkat menjadi hakim agung (Qadli al-Qudlat) di Sevilla dan dua tahun berikutnya di Cordova. Pada tahun $1182 \mathrm{M}$. dianggil ke Maroko oleh khalifah Abu Ya'qub Yusuf untuk menggantikan Ibn Thufai sebagai tabib istana sampai kemudian dimakzulkan oleh putra khalifah Abu Yusuf Ya'qub al-Manshur tahun 1194 M dengan tuduhan sebagai pelaku bid'ah karena kajian-kajian filsafatnya. Namun belakangan ia dipanggil kembali ke istana Marakesh hingga meninggal pada tahun 1198 M. jenazahnya kemudian dimakankan di tanah tumpah darahnya Cordova (Ibn Abi 'Ushaibi'ah, p. 478).

Filsuf Ibn Rusyd meninggalkan sejumlah karya besar yang hingga kini masih dibaca dan dikenal. Dalam bidang kedokteran, karyanya adalahal-Kulliyyah fi al-Thibb,yang di antaranya menyatakan bahwa orang yang telah terkena cacarair tidakakan tidak mungkin terinffeksi lagi untuk kedua kalinya. Namun begitu, Ibn Rusyd lebih dikenal sebagai filsuf dan komentator filsafat Aristotle. Karyanya 
Tahafut al-Tahafut sebagai bantahan dan jawaban terhadap tuduhan bid'ah dan kafir tokoh teolog Baghdad al-Ghazali (1058-1111 M.) terhadap filsafat, terutama al-Farabi dan Ibn Sina dalam bukunya Tahafut al-Falasifah membuat Ibn Rusyd sebagai filsuf paling terkenal dan paling besar dalam sejarah filsafat Islam.

Di antara sekian banyak filsuf abad ini, yang paling berhak menempati ketenaran setelah Ibn Rusyd adalah sang filsuf Yahudi yang sezaman dengan Ibn Rusyd, yakni Abu Imran Musa Ibn Maimun yang dikenal di Barat dengan nama Maimonides. Tokoh kedokteran dan filsafat ini lahir di Cordova pada tahun 1135 M. Namun, karena tekanan dan konflik politik dengan dinasti al-Muwahhidun, keluarganya meninggalkan Spanyol dan menetap di Kairo. Menurut beberapa riwayat, Ibn Maimun saat di Andalusia mengaku sebagai muslim, akan tetapi secaradiam-diam mengamalkan ajaran Yahudi. Di Kairo, Ibn Maimun menjadi dokter istana di masa khalifah Shalah al-Din alAyyubi dan anaknya al-Aziz dari dinasti al-Ayyubiyyah, sampai meninggal dunia tahun $1204 \mathrm{M}$.

Dalam bidang kedokteran Ibn Maimun banyak mengambil dari al-Razi, Ibn Sina dan Ibn zuhr, lalu dikembangkannya melalui penelitian-penelitian pribadinya. karyanya yang terkenal adalah alFushul fi al-Thibb.Adapun pemikiran filsafatnya dituangkannya dalam buku Dalalat al-Hairin,yang berupaya mendamaikan pemikiran Aristotelianisme Islam dengan teologi Yahudi, sangat mirip dengan gagasan Ibn Rusyd tentang penyesuaian antara agama dan intelek, meskipun tentu dari perspetif dirinya yang beragama Yahudi. Dalam perkembangannya pemikiran filsafat Ibn Maimun dipandang sebagai media yang representatif dalam menyampaikan pemikiran Yahudi kepada masyarakat Eropa, khususnya umat Kristen dan Yahudi, adalah hal yang menjadikannya berpengaruh kepada perkembangan intelektual di Eropa, termasuk tokoh filsuf Yahudi Barukh Spinoza dan tokoh pemikir Kristen Immanuel Kant.

\section{Tasawuf}

Tasawuf sering dipandang sebagai disiplin ilmu yang senantiasa mengiringi filsafat. tasawuf dikenal sebagai ilmu yang berupaya mengungkap bagian esoteris dari kehidupan seseorang untuk tujuan mencapai kedekatan tertentu dengan sang pencita alam semesta. Bahkan tidak jarang seorang filsuf memadukan olah spiritual sebagai media yang bersama dengan intelek atau akal untuk menuju satu titik tertentu dalam kedekatan dengan Tuhan, bahkan dalam kondisi tertentu yang disebut sebagai al-fana, seorang filsuf dapat bersatu dengan esensi Tuhan yang kemudian disebut al-baqa. Biasanya, dalam poin ini, tasawuf disebut sebagai tasawuf falsafi. 
Corak tasawuf model di atas yang dikenal sebagai tasawuf falsafi, juga mendominasi pemikiran tasawuf di Andalusia. Tokohtokoh filsuf besar seperti Ibn Bajjah dalam Tadbir al-Mutawahhid-nya dan Ibn Thufail dalam cerita allegorisnya Hayy ibn Yaqzhan, dapat dipandang sebagai embrio dari lahirnya tasawuf falsafi di Andalusia (Ibn Abi 'Ushaibi'ah, p. 462).

Pemikiran tasawuf falsafi di Andalusia mencapai puncaknya di tangan filsuf sufi besar yang dijuluki al-syaikh al-akbar Muhyi al-Din ibn 'Arabi (1164-1240 M.), adalah seorang tokoh sufi falsafi terbesar dalam sejarah tasawuf, lahir di Murcia dan menghabiskan sebagaian hidupnya di Sevilla sampai kemudian pergi menunaikan ibdah haji pada tahun 1202 M di Mekkah, kemudian menetap di Damaskus sampai wafat pada tahun $1240 \mathrm{M}$.

Ibn 'Arabi dipandang sebagai tokoh mazhab illuminasi atau tawauf neo-platonistik yang bermuara pada penyatuan manusia dan Tuhan, sehingga dikenal sebagai tokoh pantaisme dalam Islam. Pemikirannya tentang konsep wahdat al-wujud lahir dari perenungannya yang dalam terhadap esensi, baik yang ada pada diri manusia maupun Tuhan pencipta alam semesta, yang menurutnya hanya esensi Tuhanlah yang absolutli mutlaq, sementara yang dimiliki manusia adalah hanyalah aksidensi yang senantiasa membutuhkan esensi-Nya dan tidak dapat dipandang sebagai esensi, yang oleh karenanya esensi yang sebenarnya hanyalah Tuhan yang layak disebut sebagai eksis karena kemutlakan esensinya, inilah makna dari prinsip wahdat al-wujud Ibn 'Arabi.

Pemikiran-pemikiran filsfatinya itu dituangkan dalam karya yang monumental yang sangat memukau Al-Futuhat al-Makkiyyah, yang ditulisnya setelah perenungan-perenungannya yang dalam ketika melakukan ibadah ritual haji: tawaf dan sa'i. karyanya yang lain adalah Fushush al-Hikam.

Mazhab tasawuf illuminasi yang dikembangkan oleh filsuf sufi Spanyol terbesar Ibn 'Arabi, tersebar luas menembus lintas batas kota, menghiasi pemikiran-pemikiran tasawaf filsafati di pusat-pusat ilmu di Timur: Iraq, Persia, Mesir dan Turki. Tokoh-tokoh seperti Syihab al-Din al-Suhrawardi (1155-1191 M.) dengan filsafat illuminasi-nya, Husain ibn Manshur al-Hallaj (858-922 M.) dengan teori hulul-nya, Abu Yazid al-Busthami (804-874 M.) dengan teori al-ittihad-nya, Jalal al-Din AlRumi (1207-1273 M.) dan yang lainnya adalah mata rantai dari mazhab wihdat al-wujud-nya Ibn 'Arabi dalam bentuk casing-nya yang berbeda.

Pemikir tasawuf lain berkebangsaan spanyol adalah $\mathrm{Abu}$ Muhammad 'Abdul Haqq ibn Sab'in (1217-1260 M.). Tokoh tasawuf 
falsafi penerus Muhyi al-Din Ibn 'Arabi ini lahir di Murcia. Kedudukannya yang tinggi di kalangan para sufi pada masanya, ibn Sab'in dijuluki sebagai Qutb al-Din. Hal ini berkat jawabannya tentang berbagai persoalan agama, filsafat dan tawawuf, seperti kekekalan alam, materi, dan keabadian jiwa, dan lain-lain, yang dirangkum dalam bukunya Al-Ajwibah 'an al-As'ilah al-Siqilliyyah sebagai jawaban atas pertanyaan-pertanyaan kaisar Sicillia yang Kristen, adalah hal yang membuat kaisar Kristen itu kemudian mengundangnya untuk melakukan perbincangan denganny asecara pribadi. Atas perintah khalifah Abd al-Wahid al-Rasyid (1232-1242 M.), Ibn Sab'in kemudian tinggal di Ceuta. Karya ibn Sab'in yang lain tentang filsafat illuminasi adalah Asrar al-Hikmah al-Masyriqiyyah (Hitti, 2005, p. 749).

\section{Bidang Sains, Geografi dan Sejarah}

Astronomi adalah salah satu bidang sains yang menjadi materi inti dalam pendidikan dan pengajaran, terutama di lembaga-lembaga Tinngi. Sejak pertengahan abad 10, astronomi sudah berkembang pesat di Andalusia karena dukungan penuh dari para penguasa di hampir seluruh wilayah Andalusia, seperti Cordova, Sevilla, dan Toledo. Para ahli astronomi Arab Spanyol mengembangkan keilmuan mereka berdasarkan karya-karya astronomi yang ditulis astronomastronom wilayah Islam Timur. Mereka menemukan kembali sistem astronomi Aristotle dan membedakannya dari system Ptolemius. Mereka mendukung system astronomi Aristotle dan menyerang system astronomi Ptolemius tentang pergerakan benda-benda angkasa.

Pada periode al-Muwahhidun, yakni sekitar abad ke 11-12 dapat dipandang sebagai masa kejayaan Spanyol Islam dalam bidang astronomi. Hampir semua tokoh-tokoh filsuf yang dijelaskan pada pembahasan terdahulu adalah juga ahli dalam bidang astronomi, dari Ibn Bajjah, Ibn Thufail dan Ibn Rusyd. Nama astronom yang menghiasi langit Andalusia pada masa ini adalah Jabir Ibn Aflah (1100-1150 M.), tokoh astronomi dari Sevilla, yang berhasil mengembangkan astronomi dari pendahulu-pendahulu mereka seperti al-Majrithi al-Qurthubi (w. 1007 M.) dari al-Zarqali (w. 1029) dari Toledo. Karya Ibn Aflah yang terkenal adalah Kitab al-Hai'ah aw Ashlah al-Majesti, yang mengoreksi system astronomi Ptolemius dan menyatakan bahwa Mercurius ('Atharid) dan Venus (al-Zuhra) adalah planet yang lebih dekat ke Bumi dari pada Matahari.

Tokoh penting di antara astronom terakhir di Spanyol Islam adalah Nur al-Din Abu Ishaq al-Bitruji (w. 1204). Dikenal sebagai filsuf dan astronom lahir di Pedroche Cordova dan menetap di Sevilla, adalah murid filsuf Ibn Thufail dan semasa dengan filsuf besar Ibn Rusyd. 
Karyanya Kitab al-Hayat diterjemahkan ke dalam Ibrani dan pada tahun 1531 M. diterjemahkan ke dalam bahas Latin. Pandanganpandangan astronominya dianggap sebagai babak baru dalam bidang astronomi yang mematahkan teori Ptolemius. Al-Bithrujilah yang sebenarnya menemukan teori Heliosentrisme dalam karyanya Kitab alHai'ah tentang pergerakan planet-planet matahari, yang dengannya telah membuka wawasan baru bagi Copernicus seorang astronom yang datang belakang. Bukunya yang terakhir diterjemahkan ke dalam bahsa Latin tahun 1217 M. oleh Michael Scouts seorang astronom pada kaisar Frederick II imperium Jerman dan raja Sicillia (1194-1250 M.) dan selanjutnya diterjemahkan dalam banyak bahasa Eropa. Di penghujung abad ke-12 dan seterusnya bermunculan karya-karya terjemahan dari bahasa Arab ke bahasa Latin, baik dalam bidang astronomi, meteorologi, fisika, matematika, geografi, dan seterusnya, Hal ini berpengaruh cukup besar di dalam transliterasi istilah-istilah keilmuan dari Arab ke bahasa Eropa, misalnya dalam bidang Astrologi ada beberapa kata Acrab (al-'aqrab: scorpio), altair (al-thair: burung), deneb (al-dzanab: ekor), nadir (al-nazhir: titik penglihatan), Algebra, Algorisme, dll. (Hitti, 2005, p. 728-729).

Dalam bidang ilmu pengetahuan alam, sudah dimulai oleh fisikawan muslim dari Cordova Abu Sa'id Abd al-Rahman ibn Abdillah al-Ghafiqi (w. 732 M.) yang hidup di masa Umayyah dan dikembangkan dimasa dinasti al-Muwahhidun oleh Abu Ja'far Ahmad ibn Muhammad (w.1165 M.) dengan mengumpulkan tanaman-tanaman di Spanyol dan Afrika, yang masing-masingdiberi nama Arab, Latin dan Berber dan memberinyapenjelsanyang detail dan teliti. Karya utamanya adalah $\mathrm{Al}$ Adwiyah al-Mufradah. Buku ini kemudian menjadi rujukan bagi ilmuwan yang datang berikutnya, misalnya Abu Muhammad Abdullah ibn Ahmad al-Malqi yang lebih dikenal sebagai ibn al-Baithar (11971248 M. (Ibn Abi 'Ushaibi'ah, p. 550), seorang tokoh dalam bidang botani dan farmasi kelahiran Malaga yang sangat ahli meracik obat dan pelopor pengobatan kimia. Setelah menimba ilmu di Sevilla pada ilmuwan-ilmuwa Botani seperti Abu al-'Abbas ibn al-Rumiyyah alNabati al-Isybili (1166-1239 M.) dan Abdullah ibn Shalih al-Katami, seorang ahli botanidan farmasi pada dinasti al-Muwahhidun, ia pindah ke Maroko dan singgah di Marakesh, Aljazair, Tunis dan Tripoli sebagai peneliti dalam bidang Botani, kemudian menyebrang ke Asia Kecil, terus ke Yunani dan Romawi, dan melanjutkan perjalannya ke wilayah Timur, singgah di Persia, Irak, Syam, Hijaz, Gaza, Yerusalim, Beirut, Mesir, dan sebelum akhirnya menetap di Mesir untuk mengembangkan penelitiannya tentang tumbuh-tumbuhan. Di Mesir Ibn al-Baithar mengabdi pada sultan al-Ayyubi al-Malik al-Kamil dipercaya sebagai 
kepala para botani dan terus berlanjut di masa putranya sultan Najm al-Din Ayyub. Ibn al-Baithar meninggalkan beberapa karya, dan yang paling terkenal adalah al-Jami' li Mufradat al-Aghdziyah wa al-Adwiyah yang lebih merupakan sebuah insiklopedi botani berikut karyanya yang lain al-Mughni fi al-Adwiyah al-Mufradah.

Dalam bidang Geografi, sudah dimulai pengembangannya sejak masa Umayyah, seperti tokoh geografi Abu 'Ubaid Abdullah ibn Abd alAziz al-Bakri (w.1094) dengan karyanya al-Masalik wa al-Mamalik, dan mencapai puncaknya di abad ke-12, di masa al-Muwahhidun. Tokoh geografi dan ahli kartografi paling cemerlang adalah al-Idrisi. Seorang Arab Spanyol yang mendapatkan pendidikan tinnginya di Spanyol. Tokoh ilmuwan kelahiran Ceuta Maroko bernama Abu Abdillah Muhammad ibn Muhammad ibn Abdillah al-Idrisi al-hasyimi al-Qursyi (1099-1160 M.) dikenal sebagai sejarawan, ahli geografi dan kartografi. Pasca runtuhnya dinasti al-Muwahhidun, al-Idrisi pindah ke Sicillia di bawah naungan raja Roger II, raja Norman dari Sicillia, yang dikenal sebagai pecinta ilmu pengetahuan. Karyanya yang paling terkenal adalah Nuzhat al-Musytaq fi Ikhtiraq al-Afaq yang ditulisnya atas permintaan raja Sicillia itu (Al-Marrakisyi, 2016, p. 192).

Pada perkembangan berikutnya, ilmu geografi di Spanyol Islam banyak ditekuni oleh para pengembara. Di antaranya yang terkenal adalah Abu al-Hasan Muhammad ibn Ahmad ibn Juabair al-Andalusi (1145-1217 M.) yang memulai perjalannya dengan bertolak dari Granada tahun 1183 M. dengan menyeberangi lautan Mediterania melalui pulau-pulau Tharif dan Sicillia sampai berlabuh di Alexandria yang memakan waktu selama 30 hari. Catatan perjalanannya ditungkan dalam buku Rihlat Ibn Jubair. Ahli geografi dan penjelajah lainnya adalah Abu Hamid Muhammad al-Mazini al-Gharnathi (10801170 M.) dikenal karena penjelajahannya ke negeri-negeri Timur, yang bertolak dari negerinya ke Alexandria tahun $1114 \mathrm{M}$. dan disusul kemudian tahun 1117 M. ke Baghdad, Iran dan Khawarizm yang dirangkumnya dalam karya Tuhfat al-Albab wa Nakhbat al-I'jab. Setelah Ibn Jubair al-Andalusi dan al-Mazini kemudian muncul penjelajah-penjelajah berikutnya dan yang terbesar adalah Ibn Bathutah (1304-1377 M.) di permulaan abad ke-14 dengan karyanya sangat fenomenal hingga kini Rihlat Ibn Bathuthah (Hitti, 2005, p. 725).

Dalam bidang sejarah, dinasti al-Muwahhidun telah melahirkan sejarawan hebat bernama Abd al-Wahid al-Marakisyi (1185-1250 M.), sejarwan kelahiran Marakeh ini menulis karyanya berjudul $A l-M u$ 'jib $f i$ Tarikh Akhbar al-Maghrib.menyusul kemudian sejarawan-sejarawan lain berasal dari Andalusia, di antaranya Ibn Bashkuwal, Abdul Qasim Khalaf ibn Abd al-Malik (1101-1183 M.), lahir di Cordova dan sempat 
menimba ilmu pada sang filsuf besar Ibn Rusyd, telah menulis lebih dari 50 buku, di antara yang terkenal adalah Kitab al-Shilah: Fi TarikhAimat al-Andalus wa 'Ulamaihim wa Muhadditsihim waFuqahaihim wa Udabaihim, yang merupakan penyempurnaan dari buku Tarikh 'Ulama al-Andalus karya Ibn al-Fardli al-Andalusi (9621012 M) yang pernah menjadi hakim di Valencia di masa khalifah Muhammad al-Mahdi, yang kemudian dilanjutkan oleh Ibn al-Abar alQudla'i al-Balinsi (1199-1260 M.) dengan karya al-Takmilah li Kitab alShilah dan Kitab al-Hullah al-Suyara. Karya Ibn Basykuwal yang lain adalah Akhbar Qudlat Qurthubah. Sejarawan Spanyol lainnya adalah Abu Ja'far Ahmad ibn Yahya yang dikenal dengan Ibn 'Umairah alDlabbi (w. 1203 M.) yang telah menulis karya sejarah Bughyat alMultamis fi Tarikh al-Andalus.

\section{Bidang Keagamaan}

Sebagaimana pada periode Umayyah II, bidang keagamaan ini tentu menjadi elemen penting dari kurikulm yang diterapkan di lembaga-lembaga pendidikan dan pengajaran, terutama di Perguruan Tinggi yang kemudian mampu melahirkan tokoh-tokoh agamawan yang ahli dalam bidang Fiqih, Tafsir, Hadis, bahasa dan sastra. Salah satu mufasir yang juga ahli fiqih dan hadis terkenal di Andalusia adalah Al-Qurtubi. Nama lengkapnya adalah Abu Abdillah Muhammad bin Ahmad bin Abu Bakr bin Farh Al-Anshari Al-Khazraji Al-Andalusi (1214-1273 M). adapun karyanya dalam bidang tafsir adalah Al-Jami' li Ahkam al-Quran, kitab tafsir yang terdiri dari 20 jilid ini dikenal dengan nama Tafsir Al-Qurtubi.

Dalam bidang fiqih, Spanyol Islam sejak masa Umayyah II dikenal sebagai pusat penganut mazhab Maliki. Nama-nama ahli Fiqih seperti Yahya ibn Yahya al-Laitsi (w. 848 M.), Abu al-Hasan 'ali ibn Muhammad al-Qairuwani al-Lakhmi (1006-1085 M), Abu Bakr Muhammad ibn Umar ibnn Al-Quthiyyah (w.977 M.), Muniz bin Sa'id Al-Baluthi (877-966 M.) adalah tokoh-tokoh Fiqih penganut mazhab Maliki. Juga sang filsuf besar yang hidup di masa dinasti alMuwahhidun Ibnu Rusyd, adalah penanut Malikiyah. Ibn Rusyd yang menjabat sebagai hakim agung itu menulis fiqih komparatif monumental berjudul Bidayah Al-Mujtahid wa Nihayah Al-Muqtasid. Tradisi keilmuan dan bidang Fiqih kemudian diteruskan oleh tokoh Fiqih yang datang belakangan seperti Ibrahim ibn Musa al-Syatibi alGharnathi (w. 1388 M.), adalah penulis buku Al-Muwafaqat fi Ushul alSyari'ah dalam bidang ushul fiqih.

Pada masa periode II, Spanyol Islam banyak juga banyak dihiasi oleh tokoh-tokoh ahli dan mahir dalam bahasa Arab, diantaranya : Ibnu Sayyidih al-Mursi (1006-1066 M), seorang sastrawan pemilik karya 
Kitab al-Muhkam wa al-Muhith al-A'zham, Muhammad ibn Adbillah ibn Malik al-Thai al-Andalusi (1202-1274 M), pengarang Alfiyah tentang tata bahasa Arab. Juga Abu al-Hasan Ali ibn Muhammad ibn Ali Ibn Khuruf al-Isybili (1130-1212 M.) pensyarah Kitab Sibawaih, Abu al'Abbas Ahmad ibn Muhammad ibn Ahmad al-Azdi al-Isybili yang dikenal dengan nama Ibnu Al-Hajj (w. 1249 M), Abu Ali Al-Isybili (w. 645 H.) yang dikenal dengan al-Syalubin adalah bapak para ahli Nahwu, Abu Al-Hasan bin Usfur al-Isybili (1200-1270 M.) pengarang al-Muqrib fi al-Nahw dan al-Mumti' fi al-Tashrif, dan Abu Hayyan AlGharnathi (1256-1344 M.) yang dikenal juga sebagai ahli Tafsir dengan karyanya Tafsir al-Bahr al-Muhith.

Dalam bidang sastra pada periode ini, banyak bermunculan sastrawan Arab Spanyol, seperti Ibnu Bassam al-Syantirini (1058-1147 M.) dari Santarem penulis karya sastra Al-Dzakhirah fi Mahasih Ahl AlJazirah yang dikenal sebagai rujukan dalam bidang sastra dan peradaban di Andalusia. Juga tokoh sastrawan bernama Al-Fath bin Khaqan al-Isybili (1087-1134 M.), syair-syairnya terangkum dalam karya Qalaid al-'Uqyan, dan lain-lain.

\section{Kesimpulan}

Dari penjelasan singkat di atas, dapatlah dibuat sebuah benang merah, yang menandai geliat intelektual di Spanyol Islam periode ke-2 ini, dalam dua hal saja: pertama, kemajuan intelektual pada periode ini tidak lagi disebabkan oleh maraknya ekspedisi yang dilakukan oleh para khalifah ke dunia Islam Timur untuk membeli buku sebanyakbanyaknya dan kemudian membangun perpustakaan di Andalusia, melainkan ditandai dengan derasnya arus pemikiran yang datang dari Timur ke Barat, yakni Spanyol Islam, terutama di masa khalifah Abu Ya'qub Yusuf dan putranya Ya'qub al-Manshur, banyak sekali tokohtokoh ilmuwan Timur, Persia, Baghdad, Syam, dan Mesir yang berimigrasi ke Andalusia untuk mengembangkan keilmuannya di sana. Para ilmuwan Andalusia juga dikenal banyak yang mengembara ke dunia Timur, tapi dalam konteks sebagai penjelajah dan peneliti yang kemudian menuliskan catatan-catatan perjalanannya dalam sebuah buku perjalanan seperti Ibn Jubair, al-Mazini, Ibn Bathuthah dan seterusnya.

Kedua, pada periode inilah, yakni abad ke-12 dan 13, merupakan abad transmisi peradaban Arab Islam dari Andalusia ke benua Eropa. Hampir seluruh karya-karya induk ilmuwan Islam baik yang berasal dari negeri-negeri muslim di Timur maupun dari Spanyol Islam diterjemahkan ke dalam bahasa Latin di bawah komando Gerard dari Cremona (w. 1187 M.) yang juga dikenal sebagai penerjemah 
paling produktif yang telah menerjemah lebih dari 71 karya dari bahasa Arab ke dalam bahasa Latin, sebelum kemudian diterjemahkan de dalam banyak bahasa Eropa. Gerakan penerjemahan tersebut berpusat di Toledo, yang juga berfungsi sebagai pusat pembelajaran pengetahuan Islam. Di Toledalah, atas inisiatif uskup besar Raymond I (1126-1152 M.) dibangun suatu sekolah khusus penerjemahan. Sekolah ini mampu melahirkan sejumlah besar penerjemah dari berbagai pelosok Eropa, termasukdari kepulauan Inggris, yang mendatangkan Michel Scot (w. 1236 M.) dan Robert Chester. Pada tahun $1145 \mathrm{M}$. Robert menghasilkan karya terjemahan pertamanya berupa buku Aljabar karya al-Khararizmi, dan pada tahun $1145 \mathrm{M}$. bersama Hermann menyempurnakan terjemahan Alquran dalam bahasa Latin yang dipersembahkan kepada raja Peter. Di kota Toledo inilah didirikan sekolah kajian tentang Orientalisme yang pertama di Eropa pada tahun $1250 \mathrm{M}$. atas permintaan para pendeta dengan tujuan untuk mempersiapkan para misionaris Kristen ke kalangan umat Islam dan Yahudi.

Masyarakat Spanyol Islam merupakan masyarakat majemuk yang terdiri dari komunitas-komunitas Arab (Utara dan Selatan), alMuwalladun (orang-orang spanyol yang masuk Islam), Berber (umat Islam yang berasal dari Afrika Utara), al-Shaqalibah (penduduk daerah antara Konstantinopel dan Bulgaria yang menjadi tawanan Jerman dan dijual kepada penguasa Islam untuk dijadikan tentara bayaran), Yahudi, Kristen Mujareb yang berbudaya Arab, dan Kristen yang masih menentang kehadiran Islam. Semua komunitas itu, kecuali yang terakhir, memberikan sumbangan intelektual terhadap terbentuknya lingkungan budaya Andalusia yang melahirkan kebangkitan llmiah, sastra, dan pembangunan infrastruktur yang bernilai arsitektur tinngi di Spanyol (Hitti, 2005, p. 676). Di samping dari faktor kemajemukan masyarakatnya, negeri yang subur juga mendorong negeri Spanyol dalam mendatangkan penghasilan ekonomi yang tinggi dan pada gilirannya banyak menghasilkan pemikir.

\section{DAFTAR PUSTAKA}

'Ali, J. (1993). al-Mufashshal fi Tarikh al-'Arab Qabla al-Islam. Baghdad: Jami'ah Baghdad.

Abd al-Badi', L. (1989). Al-Islam fi Asbania. Kairo: Maktabah al-Nahdlah alMishriyyah. 
al-Fardli, I. (2008). Tarikh 'Ulama al-Andalus. Tunis: Dar al-Gharb al'Arabi.

Amin, A (1952). Yaum al-Islam. Kairo: Maktabat an-Nahdlah alMishriyyah.

- (1969). Zhuhr al-Islam. Beirut: Dar al-Kutub al-'Arabi.

(1969). Fajr al-Islam: Yabhats 'an al-Hayat al-'Aqliyyah fi Shadr al-Islam ila Akhir ad-Dawlah al-Umayyah. Beirut: Dar alKitab al-'Arabi.

Armstrong, K. (2002). Islam Sejarah Singkat (Islam: A Short History). Terj. Fungky kusnaedy Timur. Yogyakarta: Penerbit Jendela.

Hasan, I. H. (n.d.) Tarikh al-Islam as-Siyasi wa ad-Dini wa as-Saqafi wa alIjtima'i. Bairut: Dar al-Jail.

Hitti, P. K. (1974). History of Arabs. London: Macmillan Student Editions.

Katsir, I. (n.d.). Al-Bidayah wa an-Nihayah. Bairut: Maktabat al-Ma'arif.

Khalikan, I. (1978). Wafayat al-A'yan wa Anba abna al-Zaman. Beirut: Dar al-Shadir.

Lapidus, I. M. (1999. Sejarah Sosial Umat Islam (A History of Islamic Societies). Terj. Ghufron A. Mas'adi. Bagian Kedua. Jakarta: PT. Raja Grafindo Persada.

Lewis, B. (1976). Islam From The Prophet Muhammad to The Capture of Constantinopel: Politik and War. London: The Macmillan Press Ltd.

(1993). Islam in History: Ideas, People, and Events in The Middle East. New Edition, Ervised, and Expanded. Chicago: Open Court.

Marrakusyi. (2016). Al-Mu'jib fiTarikh Akhbar al-Maghrib. Beirut: alMaktabah al-'Ashriyyah.

Nahlawi, A. R. (2004). al-. Ushul al-Tarbiyah al-Islamiyyah wa Asalibuha fi al-Bait wa al-Madrasah wa al-Mujtama'. Damaskus: Dar al-Fikr. 
Rusyd, I. (1982). Fashl al-Maqal fima Baina al-Din wa al-Falsafah mialIttishal. Beirut: Dar al-Afaq al-Jadidah.

Steenbrink, K. A. (1986). Pesantren, Madrasah, Sekolah: Pendidikan Islam dalam Kurun Modern. Jakarta: LP3S.

Suwito, Fauzan. (2008).Sejarah Sosial Pendidikan Islam. Jakarta: Kencana Prenada Media Group.

Tabari, M. I. J. (1407). Al-Tarikh al-Umam wa al-Muluk (Tarikh at-Tabari. Bairut: Dar al-Kutub al-'Islamiyyah.

'Ushai'ah, I. A. (n.d.). 'Uyun al-Anba fi Thabaqat al-Athibba. Ibn al-Atsir. AlKamil fi at-Tarikh. 